\title{
KPT-330 has antitumour activity against non-small cell lung cancer
}

\author{
H Sun ${ }^{* 1,5}$, N Hattori ${ }^{2,5}$, W Chien ${ }^{2}$, Q Sun ${ }^{2}$, M Sudo ${ }^{2}$, G L E-Ling ${ }^{2}$, L Ding ${ }^{2}$, S L Lim² ${ }^{2}$ S Shacham ${ }^{3}$, M Kauffman $^{3}$, \\ T Nakamaki ${ }^{4}$ and H P Koeffler ${ }^{1,2}$ \\ ${ }^{1}$ Department of Hematology and Oncology, Cedars-Sinai Medical Center, Los Angeles, CA, USA; ${ }^{2}$ Cancer Science Institute of \\ Singapore, National Cancer Institute, NUS, Singapore, Singapore; ${ }^{3}$ Karyopharm Therapeutics, Boston, MA 01760, USA and \\ ${ }^{4}$ Division of Hematology, Department of Medicine, Showa University School of Medicine, Tokyo, Japan
}

Background: We investigated the biologic and pharmacologic activities of a chromosome region maintenance 1 (CRM1) inhibitor against human non-small cell lung cancer (NSCLC) cells both in vitro and in vivo.

\begin{abstract}
Methods: The in vitro and in vivo effects of a novel CRM1 inhibitor (KPT-330) for a large number of anticancer parameters were evaluated using a large panel of 11 NSCLC cell lines containing different key driver mutations. Mice bearing human NSCLC xenografts were treated with KPT-330, and tumour growth was assessed.
\end{abstract}

Results: KPT-330 inhibited proliferation and induced cell cycle arrest and apoptosis-related proteins in 11 NSCLC cells lines. Moreover, the combination of KPT-330 with cisplatin synergistically enhanced the cell kill of the NSCLC cells in vitro. Human NSCLC tumours growing in immunodeficient mice were markedly inhibited by KPT-330. Also, KPT-330 was effective even against NSCLC cells with a transforming mutation of either exon 20 of EGFR, TP53, phosphatase and tensin homologue, RAS or PIK3CA, suggesting the drug might be effective against a variety of lung cancers irrespective of their driver mutation.

Conclusions: Our results support clinical testing of KPT-330 as a novel therapeutic strategy for NSCLC.

Chromosome region maintenance 1/exportin-1 (CRM1, XPO1) is an important nuclear protein export receptor, which recognises the leucine-rich nuclear export signal on proteins (Fornerod et al, 1997; Fukuda et al, 1997; Ossareh-Nazari et al, 1997). Of the six known nuclear export proteins, CRM1 is a sole exporter of the nuclear export signal-containing cargo proteins such as p53, p73, CDKN1A, Rb, BRCA1, and $\mathrm{I} \kappa \mathrm{B} \alpha$ (Rodriguez et al, 1999; Huang et al, 2000; Takenaka et al, 2004; Turner et al, 2012). During initiation or progression of cancers, malignant cells appear to acquire the ability to export key nuclear proteins that influence survival and proliferation (Turner et al, 2012). Overexpression of CRM1 in cancer cells is correlated with poor survival (Noske et al, 2008; Shen et al, 2009; van der Watt et al, 2009; Kojima et al, 2013; Tai et al, 2013). High levels of CRM1 can enhance nuclear export of tumour suppressive proteins and proteins associated with drug resistance (Kau and Silver, 2003; Turner et al, 2009).
Thus, inhibition of CRM1 may be an effective anticancer therapy (Turner et al, 2012; Zhang and Wang, 2012). Leptomycin B (LMB) specifically binds and blocks CRM1 and potentially inhibits growth of various cancer cell lines, but its clinical development was discontinued due to significant toxicity (Newlands et al, 1996; Mutka et al, 2009; Pathria et al, 2012). Nevertheless, blocking CRM1 nuclear export activity either by small interfering RNA or several CRM1 inhibitors (LMB and ratjadone) can restore tumour cell sensitivity to chemotherapeutic drugs such as doxorubicin (Turner et al, 2009; Lu et al, 2012), etoposide (Turner et al, 2009), cisplatin (Takenaka et al, 2004), and imatinib mesylate (Aloisi et al, 2006). Novel, orally bioavailable small molecules, 'selective inhibitors of nuclear export' (SINEs) have recently been developed. These compounds induce apoptosis and block proliferation of cancer cells, and show potent antileukaemic activity in mice (Lapalombella et al, 2012; Ranganathan et al, 2012;

\footnotetext{
*Correspondence: Dr H Sun; E-mail: Haibo.sun@cshs.org

${ }^{5}$ These authors contributed equally to this work.
} 
Azmi et al, 2013a,b; Etchin et al, 2013a,b; Kojima et al, 2013; Salas Fragomeni et al, 2013; Tai et al, 2013; Zhang et al, 2013). SINEs synergize with doxorubicin to inhibit growth of multiple myeloma cells (Turner et al, 2012).

Non-small cell lung cancer (NSCLC) represents about $85 \%$ of lung cancers, mainly consisting of adenocarcinoma, squamous cell, and large-cell carcinomas. Overexpression of epidermal growth factor receptor (EGFR) occurs in more than $60 \%$ of metastatic NSCLC, which is correlated with a poor prognosis (Sharma et al, 2007). Lung cancer patients with mutations in the tyrosine kinase (TK) domain (exons 19 or 21) of the EGFR gene respond poorly to an EGFR TK inhibitor (TKI, geftinib or erlotinib). Indeed, acquired resistance to EGFR TKI therapy eventually occurs in nearly all patients (Ohashi et al, 2013). Resistance to EGFR TKI develops due to abnormalities in several prominent pathways including a mutation at exon 20 of EGFR, phosphatidylinositol-4, 5-bisphosphate 3- kinase, catalytic subunit alpha (PIK3CA) mutation, as well as, loss-of-function mutations of the phosphatase and tensin homologue gene leading to the constitutive activation of Akt. K-ras mutations can result in the constitutive activation of EGFR signalling pathways. Cells with these mutations will acquire resistance to EGFR TKI (Sharma et al, 2007; Stewart, 2010; Johnson et al, 2012). Therefore, because of the mark heterogeneity of NSCLC, besides manipulating components of the EGFR signalling pathways, molecular therapeutic approaches that involve simultaneously targeting several distinct pathways such as using SINEs may have therapeutic benefits (Sharma et al, 2007; Stewart, 2010; Johnson et al, 2012).

Mutations of $p 53$ are very common in lung cancer cell lines, as well as $40-90 \%$ of fresh NSCLC tumours (Stewart, 2010). The presence of $p 53$ mutations is a poor prognostic marker in patients with adenocarcinoma of the lung (Stewart, 2010). Previously, LMB was shown to induce cell death in cervical carcinoma cell lines; these cells likely expressed papilloma virus E6 associated with inactivation of p53 (Freedman and Levine, 1998; Lecane et al, 2003; Hoshino et al, 2008). The potential of a CRM1 inhibitor as a therapeutic agent against lung cancer including those with p53 alterations has not been fully investigated.

Here, we provide evidence that the SINE KPT-330 has antitumour activity both in vitro and in vivo against NSCLC cells irrespective of $p 53$ mutational status.

\section{MATERIALS AND METHODS}

Reagents and antibodies. KPT-330 was obtained from Karyopharm Therapeutics (Natick, MA, USA). Gefitinib (product number G-4408), Dasatinib (product number D-3307), Docetaxel (product number D-1000), Paclitaxel (product number P-9600), Gemcitabine (product number G-4177), and Bortezomib (product number B-1048) were purchased from LC Laboratories (Woburn, MA, USA). Panobinostat (product number S1030) was from Selleck Chemicals (Houston, TX, USA). Rapamycin (product number R0395), Actinomycin D (product number A1410), and cisplatin (product number P4394) were obtained from Sigma-Aldrich (St Louis, MO, USA). Wortmannin (product number 9951) and 4', 6-diamidino-2-phenylindole (product number 4083) were purchased from Cell Signaling Technology (Danvers, MA, USA). Flag-hCRM1 plasmid was purchased from Addgene (Cambridge, MA, USA). BioT transfection reagent was purchased from Bioland Scientific (Paramount, CA, USA). Antibodies against CRM1 (H300), cyclin D1 (A-12), c-Myc (C-19), p27 (C-19), BCL-xL (H-5), Bax (N20), PUMA (H-136), p53 (FL-393), p73 (H-79), hnRNP A1 (N-15), pifithrin- $\alpha$ (sc-45050), Z-VAD-FMK (sc-3067), and 17-DMAG (sc-202005) were obtained from Santa Cruz Biotechnologies (Dallas, TX, USA).
Antibodies against p21 (product number 2947), BCL-2 (product number 4223), Bim (product number 2933), PARP (product number 9542), Caspase-3 (product number 9661), Caspase-9 (product number 9501), and $\alpha$-tubulin (TU-02), as well as rabbit IgG and murine IgG conjugated with horseradish peroxidase (HRP) were from Cell Signaling Technology. Antibody to $\beta$-actin (product number A1978) was from Sigma-Aldrich. Rabbit antigoat IgG-conjugated HRP was from Dako.

Cell culture, drug treatment, and cell viability assays. Eleven human lung cancer cell lines (H23, H460, H820, H1299, H1975, HCC827, HCC2279, HCC2935, HCC4006, A549, and PC14) were grown in RPMI 1640 medium (Biowest, Kansas City, MO, USA) supplemented with $10 \%$ fetal bovine serum, penicillin, and streptomycin (Invitrogen, Grand Island, NY, USA) at $37^{\circ} \mathrm{C}$ and $5 \% \mathrm{CO}_{2}$. Mutational status of the NSCLC cell lines is shown in Supplementary Table S1. The cells' identity was verified by STR analysis (ATCC). Proliferation assays were performed in 96-well plates using $3 \times 10^{3}$ cells per well in $100 \mu \mathrm{l}$ for $72 \mathrm{~h}$. Cell numbers were evaluated with the use of the 3-[4,5-dimethylthiazol-2-yl]-2, 5-diphenyltetrazolium bromide (MTT) reagents (Promega, Madison, WI, USA). The absorbance of wells at $570 \mathrm{~nm}$ was measured with a microplate reader (Infinite 200; Tecan, San Jose, CA, USA). Dose-response curves were plotted to determine halfmaximal inhibitory concentrations (IC50) for the compounds using the GraphPad Prism4 (GraphPad Software, San Diego CA, USA). To determine the synergy of two drugs, they were combined at a constant ratio (based on the individual drug's IC50) at nine concentrations. Synergy was determined using the CalcuSyn software (BioSoft, Cambridge, UK). The extent of drug interaction between the two drugs was presented using the combination index (CI) for mutually exclusive drugs. Different CI values were obtained when solving the equation for different concentrations of drugs. A CI of 1 indicates an additive effect, whereas a CI of $<1$ denotes synergy. For the cell viability assays, NSCLC cells were seeded into 96-well plates and treated for $72 \mathrm{~h}$ with drugs.

Apoptosis and cell cycle assays. Cells were seeded at 50\% confluency in $6 \mathrm{~cm}$ plates. After overnight incubation, culture media were removed and replaced with media containing either diluent control or various concentrations of indicated drugs.

Table 1. Quantitative RT-PCR primer sequences

\begin{tabular}{|c|c|}
\hline $\begin{array}{l}\text { Oligonucleotide } \\
\text { name }\end{array}$ & Sequence \\
\hline p53-F & 5'-CTGAGGTTGGCTCTGACTGTACCACCATCC-3' \\
\hline p53-R & 5'-CTCATTCAGCTCTCGGAACATCTCGAAGCG-3' \\
\hline BCL-XL-F & 5'-GCAGGCGACGAGTTTGAACT-3' \\
\hline BCL-XL-R & 5'-GTGTCTGGTCATTTCCGACTGA-3' \\
\hline Bax-F & 5'-TGACATGTTTTCTGACGGCAAC-3' \\
\hline Bax-R & 5'-GGAGGCTTGAGGAGTCTCACC-3' \\
\hline Noxa-F & 5'-GAGATGCCTGGGAAGAAGG-3' \\
\hline Noxa-R & 5'-ACGTGCACCTCCTGAGAAAA-3' \\
\hline P53AIP1-F & 5'-AGCTCACTCCGAAAGCCTCTGCTC-3' \\
\hline P53AIP1-R & 5'-GCATCACCGAGAGGTTCTGGTCTC-3' \\
\hline PUMA-F & 5'-ACGACCTCAACGCACAGTACGAG-3' \\
\hline PUMA-R & 5'-AGGAGTCCGCATCTCCGTCAGTG-3' \\
\hline p73-F & 5'-TTCAACGAAGGACAGTCTG-3' \\
\hline p73-R & 5'-CAGGGTCATCCACATACTG-3 \\
\hline CRM1-F & 5'-CTCGTCAGCTGCTTGATTTC-3' \\
\hline CRM1-R & 5'-CTCTTGTCCAAGCATCAGGA-3 \\
\hline
\end{tabular}


After $24 \mathrm{~h}$, cells were washed with phosphate-buffered saline, trypsinized, washed once with phosphate-buffered saline and resuspended in annexin-binding buffer (BD Biosciences, San Jose, CA, USA) at $1 \times 10^{6}$ cells per $\mathrm{ml}$. Cells were stained with propidium iodide (BD Biosciences) and annexin V (BD Biosciences) according to the manufacturer's protocol and assayed on a LSRII flow cytometer (BD Biosciences). Cell cycle analyses were performed by propidium iodide staining (Sigma-Aldrich) for DNA content and flow cytometric analysis.

Proteins, lysates, fractionation, immunoblotting, immunofluorescence, and immunohistochemistry. Protein lysates from cells were extracted using ProteoJET Mammalian Cell Lysis Reagent (Thermo Scientific, Waltham, MA, USA). Protein concentrations were determined by bicinchoninic acid assay (Thermo Scientific). Protein lysates were resolved by sodium dodecyl sulphatepolyacrylamide gel electrophoresis, transferred to Immobilon-P PVDF membrane (Merck Millipore, Billerica, MA, USA), and membranes were blocked for $1 \mathrm{~h}$ with TBS containing 5\% non-fat dry milk and $0.5 \%$ Tween 20 (TBST). After blocking, the PVDF membrane was incubated with primary antibody at $4{ }^{\circ} \mathrm{C}$ overnight.
The following day, the membrane was washed with T-TBS and incubated for one hour with a secondary antibody-HRP conjugate at room temperature. After washing the PVDF membranes with T-TBS, proteins were visualised with SuperSignal chemiluminescent hrp substrates (Thermo Scientific). To prepare nuclear and cytoplasmic extracts, cells were lysed in $10 \mathrm{~mm}$ HEPES ( $\mathrm{pH} 7.9$ ), $10 \mathrm{~mm}$ KCL, $0.1 \mathrm{~mm}$ EDTA, $0.1 \mathrm{~mm}$ EDTA, 0.6\% NP-40, $1 \mathrm{~mm}$ DTT, and protease inhibitors (Thermo Scientific) and centrifuged at $16000 \mathrm{~g}$ for $10 \mathrm{~min}$ to collect soluble fractions (cytosolic extracts). Insoluble material was washed with the lysis buffer (20 mm HEPES ( $\mathrm{pH}$ 7.9), $0.4 \mathrm{M} \mathrm{NaCl}, 1 \mathrm{~mm}$ EDTA, $1 \mathrm{~mm}$ EDTA, $0.6 \%$ NP-40, $1 \mathrm{~mm}$ DTT, and protease inhibitors ) and centrifuged at $16000 \mathrm{~g}$ for $10 \mathrm{~min}$ to collect the nuclear extracts. The nuclear and cytoplasmic fractions were subjected to immunoblot analysis using either anti-hnRNP A1 antibody or anti- $\alpha$-tubulin monoclonal antibody.

For immunohistochemistry, tumour tissues were fixed in formalin, embedded in paraffin, cut into $5.0 \mu \mathrm{m}$ sections. Endogenous peroxidase on these slide preparations were quenched using $3 \% \mathrm{H}_{2} \mathrm{O}_{2}$ in distilled water. Sections were blocked for $1 \mathrm{~h}$ at room temperature in phosphate-buffered saline containing $3 \%$
A
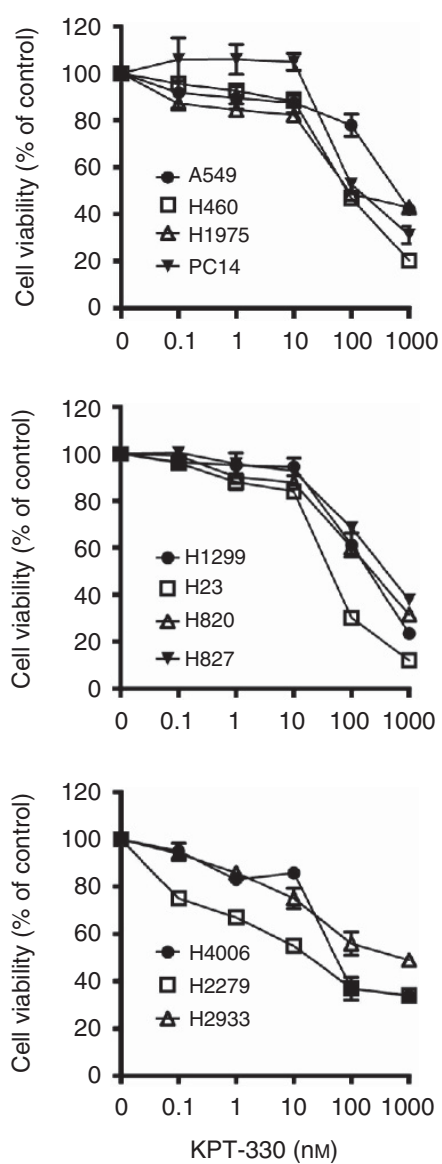

\begin{tabular}{ccc} 
NSCLC & $\mathrm{IC}_{50}(\mathrm{nM})$ & $\mathrm{p} 53$ WT \\
\hline A549 & 781 & + \\
H460 & 93 & + \\
H1975 & 148 & - \\
PC14 & 196 & - \\
H1299 & 285 & - \\
H23 & 68 & - \\
H827 & 489 & + \\
H4006 & 78 & NA \\
H2279 & 25 & - \\
H2933 & 995 & - \\
H820 & 294 & -
\end{tabular}

B
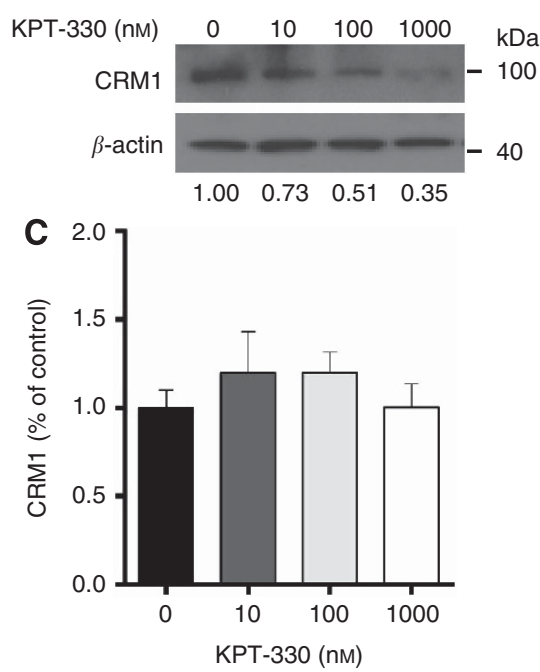

D

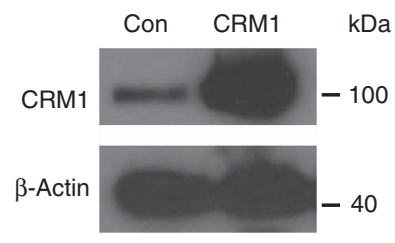

E

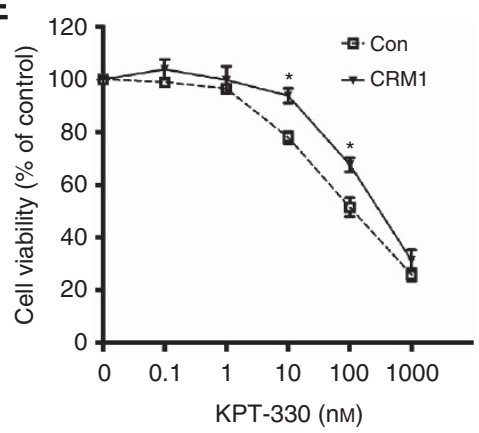

Figure 1. Effects of KPT-330 on the growth of NSCLC cells. (A) Cell viability of 11 NSCLC cell lines. Cells were seeded (3 $\times 10^{3}$ cells per well) in 96-well plates; treated with different concentrations of KPT-330 (0, 0.1, 1, 10, 100, and $1000 \mathrm{~nm}, 72 \mathrm{~h}$ ), and growth inhibition was measured by MTT assay. Dose-response curves were plotted to determine IC50 values using the GraphPad Prism 4 (left). IC50 values (nM) were calculated as described in Materials and Methods. In addition, p53 status (WT, + ; mutant, - ) is provided (right). (B, C) H1975 NSCLC cells were treated with $\operatorname{KPT}-330(0,10,100$, and $1000 \mathrm{~nm}, 24 \mathrm{~h})$, and either whole-cell lysates or mRNA were analysed for expression of CRM1 and $\beta$-actin by immunoblot (B) (densitometric analysis was carried out using ImageJ 1.46) or by quantitative RT-PCR (C), respectively. RT-PCR data represent mean \pm s.d. of experiments done in triplicate. (D) H1975 cells were stably transfected with flag-CRM1 vector or vector control (Con); CRM1 expression was evaluated by immunoblot. (E) Dose-response curves of H1975 cells with either CRM1 overexpression or vector control cells (empty vector) following treatment with different concentrations of KPT-330 (0, 10, 100, and $1000 \mathrm{~nm})$ or diluent control (Con). Results represent the mean \pm s.d. of three experiments done in triplicate. Cell viability was determined using MTT assay after $72-\mathrm{h}$ treatment. ${ }^{\star} P<0.05$. NA, not available. 
normal serum and incubated overnight at $4{ }^{\circ} \mathrm{C}$ with primary antibody for either TUNEL assay or against Ki-67. Biotinconjugated secondary antibody $(1: 200)$ and avidin-biotin peroxidase complex were then applied to the sections. Data from three randomly selected fields of view per section were captured using a microscope (Olympus, Tokyo, Japan) at $\times 200$ magnifications. TUNEL- and Ki-67-positive cells were counted using ImageJ software (NIH, Bethesda, MD, USA) and expressed as a percentage of total cells counted.

Quantitative RT-PCR. Total RNA from cells was extracted using AxyPrep Multisourse Total RNA Miniprep Kit (Axygen, Tewksbury, MA, USA) according to the manufacturer's protocol. First-strand cDNA was synthesised from total RNA using Maxima First Strand cDNA Synthesis Kit for RT-PCR (Thermo Scientific). Gene expression levels were measured by 7500 Fast Real-Time PCR System (Applied Biosystems, Beverly, MA, USA) using the KAPA SYBR FAST qPCR Kits (Kapa Biosystems, Woburn, MA, USA). Expression of each gene was normalised to $\beta$-actin as a reference. The forward and reverse primer sequences have been previously described (Leong et al, 2007). The conditions for all quantitative RT-PCR reactions are as follows: $2 \mathrm{~min}$ at $95^{\circ} \mathrm{C}$ followed by $15 \mathrm{~s}$ at $95^{\circ} \mathrm{C}$ and $30 \mathrm{~s}$ at $60^{\circ} \mathrm{C}$ for 40 cycles. All PCR products were confirmed by the presence of a single peak upon melting curve analysis and by gel electrophoresis. Primers used for all quantitative RT-PCR were listed on Table 1.

shRNA and lentiviral infections. The shRNA constructs in the pLKO.1 lentiviral vector with the following target sequences were used.

shCRM1, 5'-GCTCAAGAAGTACTGACACAT-3'

shp73, 5'-CCAAGGGTTACAGAGCATTTA- $3^{\prime}$

shp53-1, 5'-CACCATCCACTACAACTACAT-3'

shp53-2, 5'-CGGCGCACAGAGGAAGAGAAT-3'
Viral particles were made by transfection of $293 \mathrm{~T}$ cells. Target cells were incubated with lentiviruses in the presence of $8 \mathrm{mg} \mathrm{ml}^{-1}$ polybrene for $16 \mathrm{~h}$ followed by replacement of the lentivirus-containing media with fresh media. Two days after infection, Puromycin $\left(2 \mathrm{mg} \mathrm{ml}^{-1}\right)$ was added for 3 days to eliminate uninfected cells.

Animal models. NOD/SCID mice were purchased from Cancer Science Institute of Singapore (Dr Shin Leng). All animal studies were conducted according to protocols approved by the National University of Singapore Institutional Animal Care and Use Committee (IACUC). Seven-week-old male NOD/SCID mice were inoculated subcutaneously in both flanks with a suspension of H1975 $\left(1.0 \times 10^{7}\right.$ cells $)$ with matrigel. Tumour volumes were measured thrice weekly with calipers and were calculated using the following formula: volume $\left(\mathrm{mm}^{3}\right)=(\text { width }(\mathrm{mm}))^{2} \times$ length $(\mathrm{mm}) / 2$. Mice were randomly divided into two groups (five mice pergroup): orally treated with vehicle $(0.6 \% \mathrm{w} / \mathrm{v}$ aqueous Pluronic F-68 (Karyopharm Therapeutics)) or KPT-330 (10 $\mathrm{mg} \mathrm{kg}^{-1}$, thrice weekly for 4 weeks). Mice were given Nutri-Cal (tomlyn) during therapy to allow robust nutrition.

Statistics. Differences between conditions were analysed using either paired or unpaired two-tailed Student's t-test. One-way analysis of variance was used for comparisons among multiple groups. Differences were considered significant for $P<0.05$.

\section{RESULTS}

KPT-330 suppresses the growth of NSCLC cells. The antiproliferative activity of KPT-330 against 11 NSCLC cell lines was examined using MTT assay. KPT-330 (0.1-1000 nM) induced a
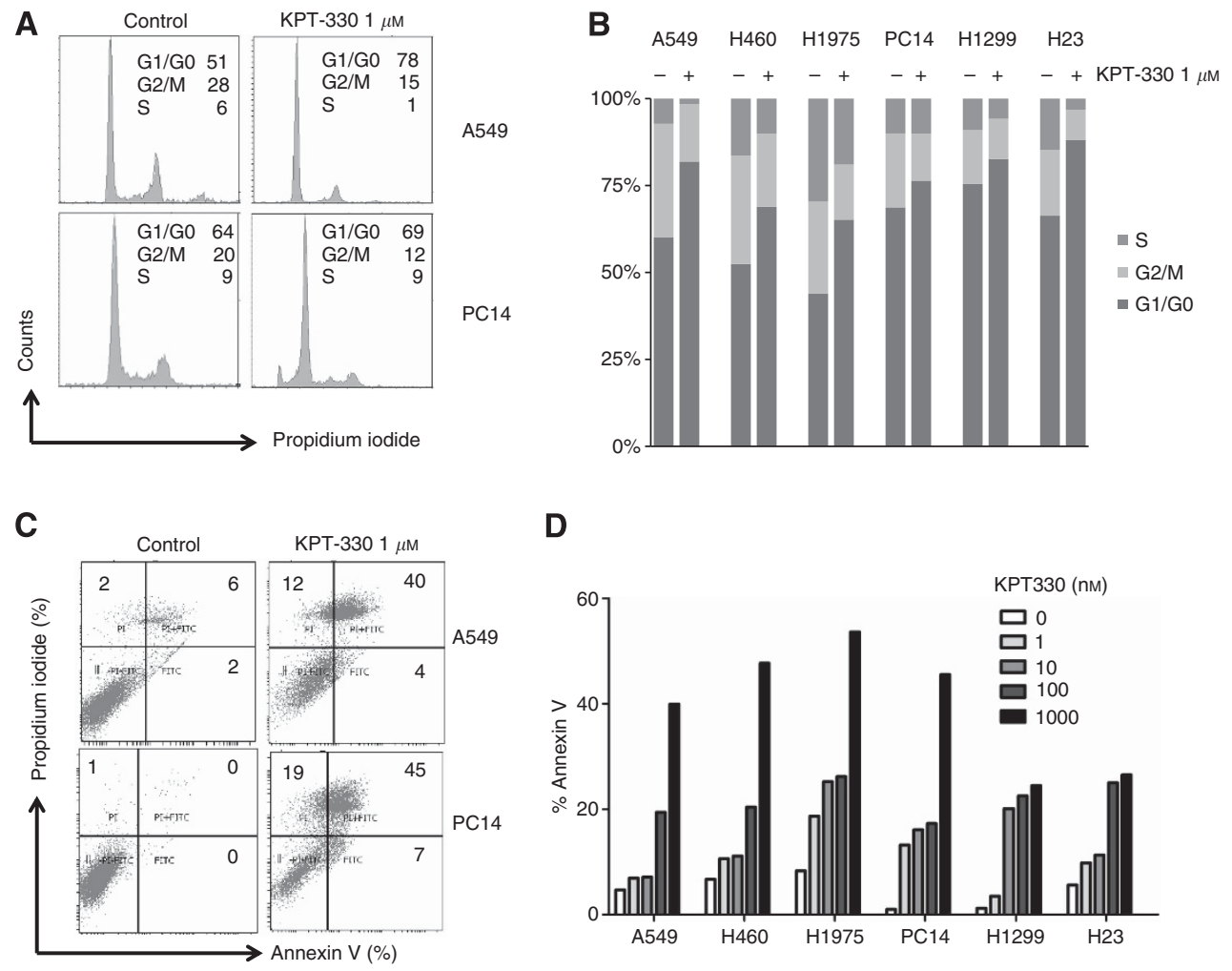

Figure 2. KPT-330-treated NSCLC cells: measurement of cell cycle and apoptosis. (A, B) Cell cycle of NSCLC cells (A549, H460, H1975, PC14, $\mathrm{H} 1299$, and $\mathrm{H} 23$ ) was analysed by flow cytometry after treatment with KPT-330 (1 $\mu \mathrm{M}, 24 \mathrm{~h})$ vs diluent control. Representative tracings of cell cycle of A549 and PC14 are displayed in panel A. (C, D) Cells were analysed by flow cytometry for apoptosis (annexin V/propidium iodide positivity) after exposure to either KPT-330 (1, 10, 100, and $1000 \mathrm{~nm})$ or diluent control for $24 \mathrm{~h}$. Representive tracing of apoptosis analysis of A549 and PC14 is shown in panel $\mathbf{C}$. 
dose-dependent growth inhibition after $72 \mathrm{~h}$ of exposure. The calculated IC50 values ranged from 25 to $995 \mathrm{~nm}$ (Figure 1A). Western blot analysis of H1975 cell lysate in the presence of increasing concentrations of KPT-330 (10-1000 nM) showed a dose-dependent decrease in protein levels of CRM1 (Figure 1B), but no significant change in its mRNA levels (Figure 1C). To confirm that KPT-330 in lung cancer cells is specifically targeting CRM1, we stably overexpressed CRM1 in H1975 cells which was identified by western blotting (Figure 1D). H1975 cells with forced expression of CRM1 displayed significantly increased resistance to KPT-330 treatment (10 and $100 \mathrm{~nm}$, Figure 1E).

KPT-330 promotes G1 arrest and apoptosis. Cell cycle distribution was determined by propidium iodide staining of six NSCLC cell lines (A549, H460, H1975, PC14, H1299, and H23) exposed to KPT-330 $(1 \mu \mathrm{M}, 24 \mathrm{~h})$ (Figure 2A and B). All six NSCLC cell lines had an increase of the G1 cell cycle (range: 56-82\%), and a decrease in the S (range: 8-20\%) and G2/M (range: 2-20\%) phases in response to KPT-330 (Figure 2B). Apoptosis was examined using annexin $\mathrm{V}$ combined with propidium iodide staining
(Figure 2C and D). A clear dose-dependent increase in the percent of annexin $\mathrm{V} /$ propidium iodide co-positive cells occurred in the six NSCLC cell lines after cultured in KPT-330 (1, 10, 100, and $1000 \mathrm{~nm}$ for $24 \mathrm{~h}$ ) (Figure 2D). The range of apoptosis induced by KPT-330 was $22-54 \%$.

Effect of KPT-330 on wild type (wt) and mutant (mut) p53 NSCLC cells. p53 wild type (p53-wt, A549) and mutant (p53-mut, PC14) NSCLC cells treated with KPT-330 (1 $\mu \mathrm{M}, 24 \mathrm{~h})$ resulted in dramatic change in key cell cycle and cell death pathways in both cell lines (Figure 3A and B). KPT-330 stimulated activation of caspase- 3 and -9 , causing PARP cleavage associated with increased levels of pro-apoptotic mediators (Bax, Bim, and Puma) and slightly decreased levels of anti-apoptotic proteins (Bcl-2 and Bcl-xL). Cell cycle inhibitors CDKN1A and CDKN1B were upregulated, while CCND1 and c-Myc were downregulated in the presence of KPT-330 (Figure 3A). These changes in protein expression $\pm \mathrm{KPT}-330$ were similar when comparing p53-wt (A549) and mut-p53 (PC14) NSCLC cells. p53 and its family member (e.g. p73) are active either in cell cycle arrest and DNA

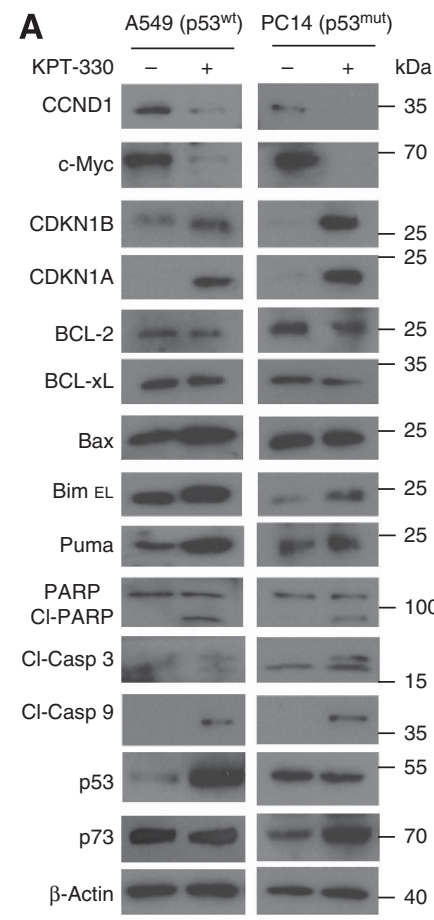

B


$\mathbf{F}$

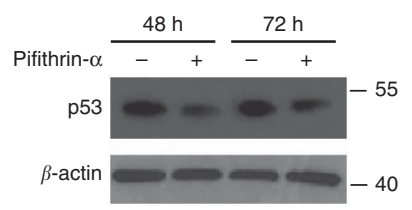

G
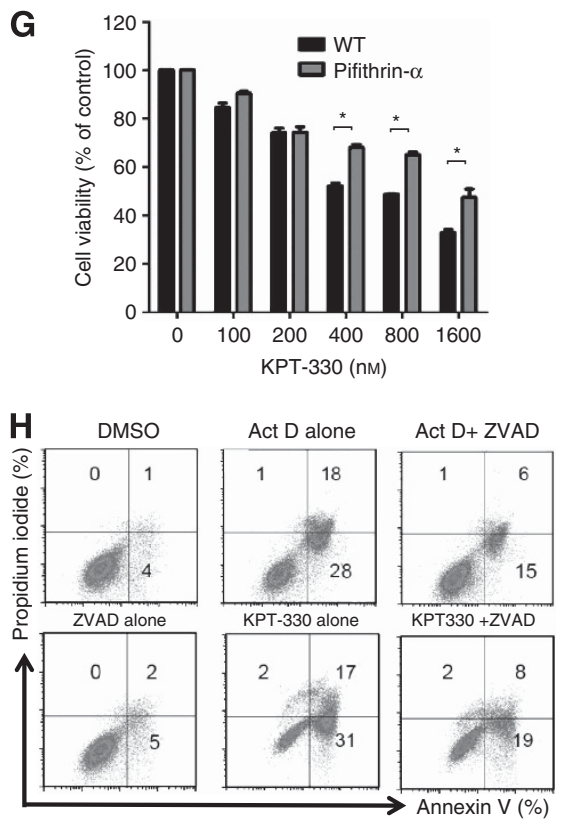

Figure 3. Cellular events after exposure of NSCLC cells to KPT-330. A549 cells (p53-wt) and PC14 cells (p53-mut) were exposed to KPT-330 $(1 \mu \mathrm{M}, 24 \mathrm{~h})$, harvested followed by either (A) whole-cell protein extractions or (B) nuclear (confirmed, hnRNP A1) and cytoplasmic (confirmed, $\alpha$-tubulin) protein extractions, or (C) total RNA. Protein was immunoblotted and probed with antibodies specific for various proteins. RNA was analysed for apoptosis-related genes (quantitative RT-PCR). (D) A549 cells were stably infected with either one of two shp53 vectors (shp53-1, shp53-2) or scrambled vector. p53-knockdown efficiency was evaluated by quantitative RT-PCR. (E) Growth curves of A549 NSCLC cells stably containing either shp53 or scrambled vectors following their exposure (72 h) to different concentrations of KPT-330 (0, 10, 100, and 1000 nM). Cell viability (MTT assay) was determined after 72-h treatment. (F) Decrease expression of p53 mediated by pifithrin- $\alpha$. A549 cells were exposed to either pifithrin- $\alpha(5 \mu \mathrm{M}, 48$ and $72 \mathrm{~h})$ or diluent control, harvested and whole-cell extractions prepared for immunoblot. (G) Dose-response assay of A549 cultured in either diluent (WT) or pifithrin- $\alpha(5 \mu \mathrm{M})$ plus various concentrations of KPT-330 $(0,100,200,400,800$, and $1600 \mathrm{nM})$. Cell viability was determined using MTT assay after $72 \mathrm{~h}$ treatment. (H) A549 Cells analysed by flow cytometry for apoptosis (annexin V/propidium iodide positivity) after exposure to actinomycin D alone (Act D, $100 \mathrm{ng} \mathrm{ml}^{-1}$ ), Act D + Z-VAD-FMK, Z-VAD-FMK (10 $\left.\mu \mathrm{m}\right)$ alone, KPT-330 (1000 nM) alone, KPT-330 + Z-VAD-FMK, or DMSO diluent control for $24 \mathrm{~h}$. RT-PCR data and growth curves represent mean \pm s.d. of three experiments done in triplicate wells. ${ }^{\star} P<0.05$. 
repair, or apoptosis if the DNA damage of the cell is too severe to be repaired. The $p 53$ family member, $p 73$, can help to regulate p53-dependent genes in p53-deficient cells (Vilgelm et al, 2008) and has become a potential therapeutic target for treating p53mutant cancers (Irwin et al, 2003). KPT-330 increased levels of wild-type p53 in A549 and levels of p73 in PC14 (mutant p53) (Figure $3 \mathrm{~A}$ and B). Bax, p53AIP, Noxa, and Puma are pro-apoptotic mediators of cell death and are known targets of both p53 and p73. KPT-330 $(1 \mu \mathrm{M}, 24 \mathrm{~h})$ induced their expression in both cell lines, albeit more profoundly in the p53-wt cells (A549) (Figure 3C). To identify whether p53 is important for KPT-330dependent antiproliferative effects in p53-wt NSCLC cells, we stably expressed two lentivirus vector-based shp53 (shp53-1 and shp53-2) in A549 cells. Compared with scramble vector control, shp53-1 and shp53-2 stably infected cells achieved $31 \%$ and $49 \%$ knockdown efficiency as measured by western blotting, respectively (Figure 3D). p53-knockdown A549 cells (shp53-1 and shp53-2) developed significant cell resistance to several concentrations of KPT-330 (100 and $1000 \mathrm{~nm}$, Figure 3E). Also, pifithrin- $\alpha$ is a potent agonist of $\mathrm{p} 53$, which can decrease both the nuclear stability and the basal DNA-binding activity of p53 in many cells (Komarov et al, 1999; Murphy et al, 2004; Sohn et al, 2009). A549 cells exposed to pifithrin- $\alpha(5 \mu \mathrm{M})$ had decreased levels of p53 (48 h and $72 \mathrm{~h}$ ) (Figure $3 \mathrm{~F}$ ), p $21^{\mathrm{cip} 1}$, and Mdm2 (Supplementary Figure S1). Similar to p53-knockdown cells, A549 cells exposed to pifithrin $\alpha(5 \mu \mathrm{M})$ were more resistant to the antiproliferative effect of KPT-330 (Figure 3F). The apoptosis induced by KPT-330 (cleavage of caspase-3 and -9 , as well as polyADP ribose polymerase (PARP) (Figure 3A)) was inhibited by caspase inhibitor Z-VAD-FMK $(10 \mu \mathrm{M})$ in the A549 cells (Figure $3 \mathrm{H})$. As a positive control, Z-VAD-FMK decreased apoptosis induced by Actinomycin D (Figure 3H).
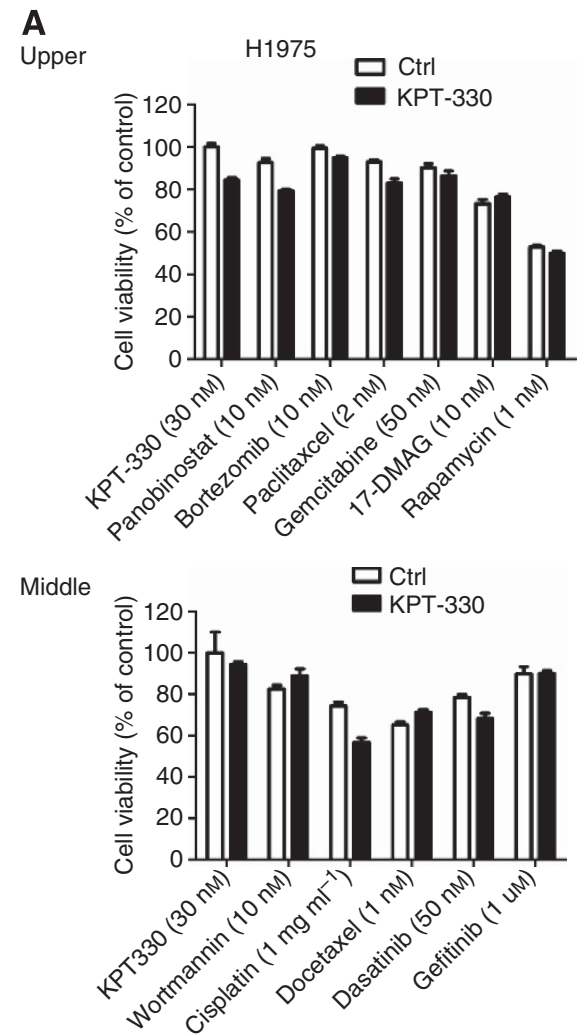

Lower

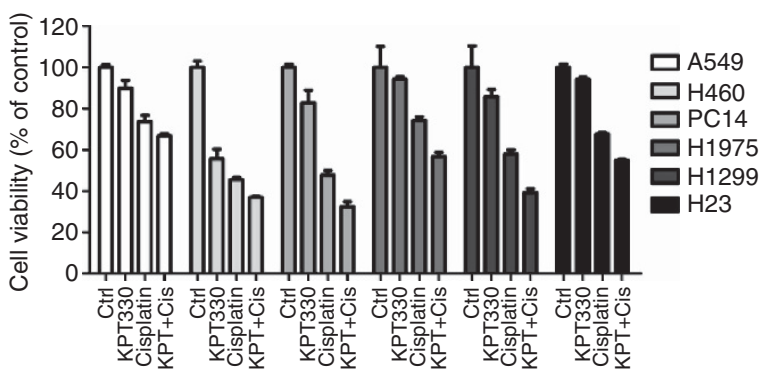

B

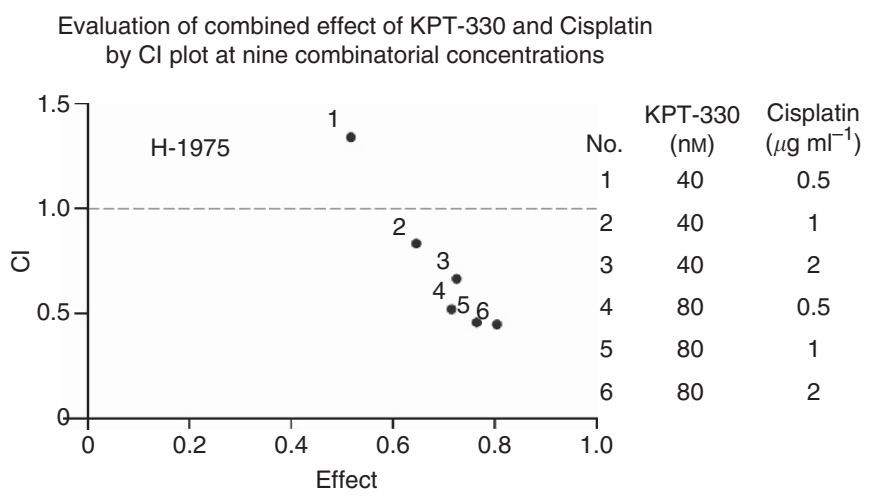

C

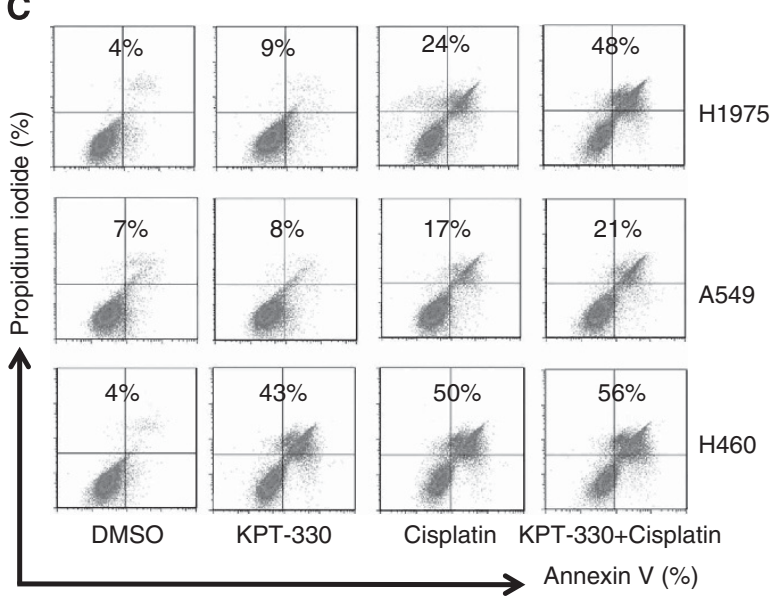

Figure 4. Drug combinations with NSCLC cells. (A) Upper and middle panel: H1975 cells were cultured with either KPT-330 (30 nM), diluent (control), experimental drug, or experimental drug + KPT-330 ( + KPT) for $72 \mathrm{~h}$, and cell viability was determined by MTT. Lower panel: combination of KPT-330 with cisplatin cultured with each of six NSCLC cell lines. In each group of four: 1st rectangle is control, 2nd, KPT-330, 3rd, cisplatin, and 4th, combination of KPT-330 and cisplatin. Concentrations of KPT-330 and cisplatin were based on the IC50 of each drug for each NSCLC cell lines. (B) Combinatorial effect of KPT-330 and cisplatin on H1975 displayed as the Cl. Cl defines the interaction between KPT-330 and cisplatin as plotted against the fraction of cell viability. $\mathrm{Cl}$ values: 1 , additive; $<1$, synergistic; $>1$, antagonistic. Table to the right defines each tested concentration of KPT-330 and cisplatin. (C) Cells analysed by flow cytometry for apoptosis (annexin V/propidium iodide positivity) after exposure to either KPT-330 (500 nm); cisplatin $\left(1 \mu \mathrm{g} \mathrm{ml}^{-1}\right)$; KPT-330 + cisplatin, or DMSO diluent (control) for $24 \mathrm{~h}$. Numbers in the figure represent percentage of apoptotic cells (annenxin $\mathrm{V}$ alone $+\mathrm{PI}$ alone + double positive). 
KPT-330 and cisplatin synergy. H1975 NSCLC cells were treated with KPT-330 (30 nM) and 11 additional therapeutic drugs (wortmannin $(10 \mathrm{nM})$, cisplatin $\left(1 \mu \mathrm{g} \mathrm{ml}^{-1}\right)$, docetaxel (1 nM), dasatinib $(50 \mathrm{~nm})$, gefitinib $(1 \mu \mathrm{M})$, panobinostat $(10 \mathrm{~nm})$, bortezomib (10 nM), paclitaxel (2 nM), gemcitabine (50 nM), 17-DMAG $(10 \mathrm{~nm})$, and rapamycin (1 nM)) (Figure 4A, upper and middle panels). The concentrations of the drugs were based on doseresponse proliferation experiments against H1975 cells (data not shown). The combination of cisplatin and KPT-330 had greater antiproliferative activity than either drug alone against six NSCLC cell lines (Figure 4A, lower panel). Cisplatin is often given to patients with NSCLC either as adjuvant therapy or those with progressive disease. Therefore, the combinatorial effect of KPT-330 with cisplatin was evaluated using six different paired combinations of KPT-330 (40 and $80 \mathrm{nM}$ ) and cisplatin (0.5, 1, and $2 \mu \mathrm{g} \mathrm{ml}^{-1}$ ) against $\mathrm{H} 1975$ NSCLC cell lines. The data were placed on a CI plot (Figure 4B). Synergistic effects were observed with KPT-330 at either 40 or $80 \mathrm{~nm}$ and cisplatin at either $0.5,1$, or $2 \mu \mathrm{g} \mathrm{ml}^{-1}$ (CI values of $0.816,0.648,0.514,0.441$, and 0.418 (No. 2, 3, 4, 5, and 6, respectively). In addition, the combination of KPT-330 and cisplatin increased apoptosis of H1975 > H460 > A549, which was greater than either drug alone (Figure 4C).

Silencing CRM1 sensitises NSCLC cells to cisplatin. As proof of principal, CRM1 was silenced in order to determine whether the
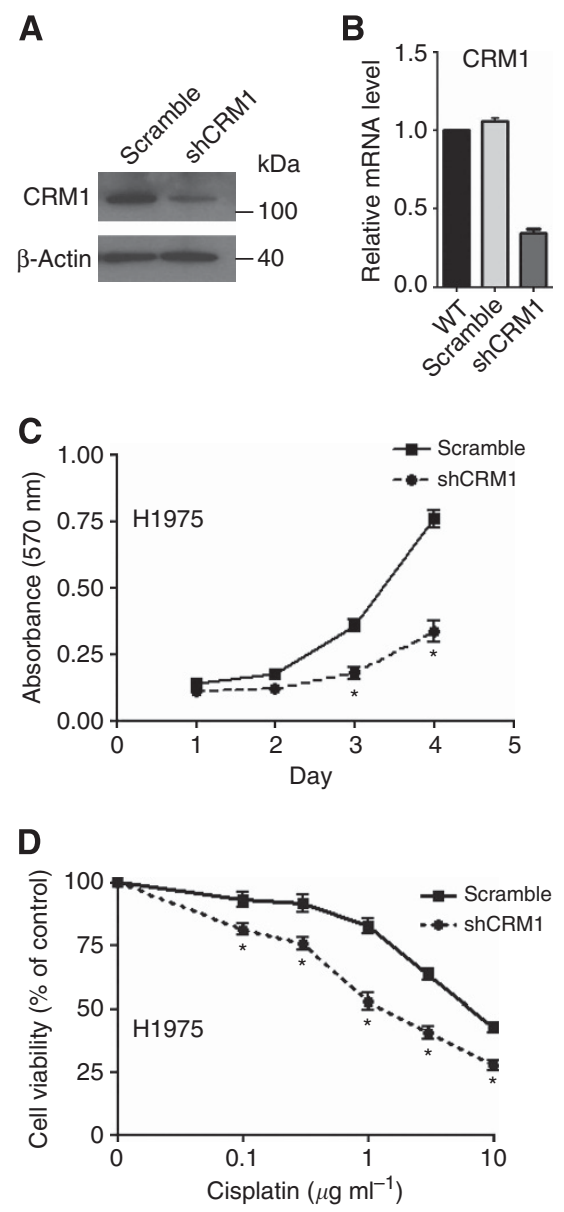

observed synergistic activity of KPT-330 and cisplatin could be produced in another model system. H1975 cells were stably infected with the pLKO.1 lentiviral vector expressing shCRM1. Efficient shRNA was confirmed by immunoblot (60\% knockdown) (Figure 5A) and quantitative RT-PCR (66\% knockdown) (Figure 5B). CRM1-knockdown cells had significantly slower growth than those stably carrying a scrambled vector (Figure $5 \mathrm{C}$ ). The CRM1 knockdown of NSCLC cells and the scramble vector carrying control cells were treated with different concentrations of cisplatin $\left(0.01-10 \mu \mathrm{g} \mathrm{ml}^{-1}\right)$ for $72 \mathrm{~h}$, and cell numbers were assayed by MTT. Compared with control cells, CRM1-knockdown cells cultured with cisplatin had enhanced antiproliferative activity compared with scrambled carrying cells also exposed to cisplatin (IC50, shCRM1, $1.62 \mu \mathrm{g} \mathrm{ml}^{-1}$ vs scramble, $8.1 \mu \mathrm{g} \mathrm{ml}^{-1}$ (Figure 5D). Moreover, upon exposure to cisplatin $\left(1 \mu \mathrm{g} \mathrm{ml}^{-1}\right.$, $24 \mathrm{~h}$ ), the CRM1-knockdown cells had elevated levels of Bim and Puma compared with control cells (scramble control + cisplatin) (Figure 5E). Likewise, mRNA expression of Puma was significantly enhanced in the CRM1-knockdown cells cultured with cisplatin compared with a similar treatment of the control cells carrying the scramble vector (Figure 5F).

shp73 reduces sensitivity to KPT-330 in NSCLC cells. The p73 was stably silenced (shp73) to explore the importance of p73 in mediating the antiproliferative effect of KPT-330 on NSCLC cells

\section{E}
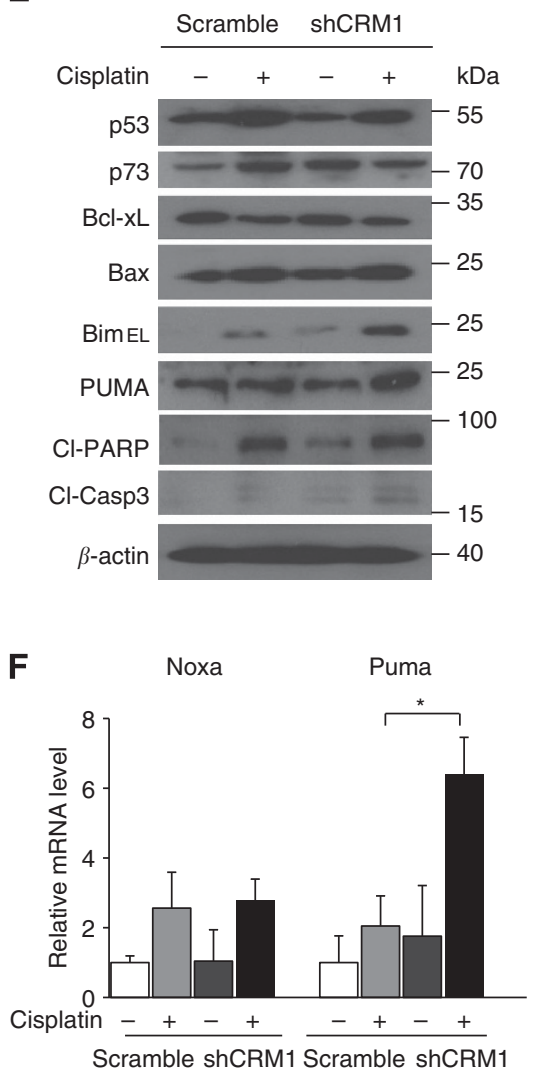

Figure 5. Effects of silencing of CRM1 in H1975 NSCLS cells. H1975 cells were stably infected with either a CRM1-specific shRNA (shCRM1) or scrambled shRNA (scramble) control. CRM1-knockdown efficiency was evaluated by immunoblot (A) and quantitative RT-PCR (B). (C) Cell proliferation of these cells was measured by MTT assay after 1-4 days of culture. (D) Cell growth (MTT assay) of H1975 cells stably containing either shCRM1 or scrambled vector cultured $(72 \mathrm{~h})$ with different concentrations of cisplatin $\left(0.1-10 \mu \mathrm{g} \mathrm{ml}^{-1}\right)$. (E, F) H1975 cells stably carrying either shCRM1 or scrambled vector were cultured \pm cisplatin $\left(1 \mu \mathrm{g} \mathrm{ml}^{-1}, 24 \mathrm{~h}\right)$ and whole-cell extracts were examined by immunoblot and $(\mathbf{F})$ total RNA was examined by quantitative RT-PCR $(E)$. Antibodies for western blotting were as indicated. Results for panels B, C, D, and F represent the mean \pm s.d. of three experiments done in triplicate. ${ }^{\star} P<0.05$. 
having a mutant p53. H1975 cells were stably infected with the pLKO.1 lentiviral vector expressing shp73. Efficient shRNA was confirmed by immunoblot (p73, 60\% knockdown) (Figure 6A) and by quantitative RT-PCR (64\% knockdown) (Figure 6B). Growth of the p73-knockdown NSCLC cells was slightly faster than the vector control cells (stable scramble vector) (Figure 6C). Also, the p73-knockdown cells were more resistant to the growth inhibitory effects of KPT-330 (IC50, scramble, $98 \mathrm{~nm} v s$ shp73, > $1000 \mathrm{~nm}$ ) (Figure 6D). Transiently silence of p73 (44\% knockdown, Supplementary Figure S2A) in PC14 cells were also more resistant the treatment of KPT-330 compared with the vector control cells (IC50, scramble, $197 \mathrm{~nm}$ vs shp73, $318 \mathrm{~nm}$ ) (Supplementary Figure S2B). In addition, p73-knockdown cells exposed to KPT-330 had decreased apoptosis (Figure 6E), decreased levels of cleaved PARP and caspase-3, as well as lower levels of BimEL (Figure 6F) compared with the scramble vector + KPT-330. Likewise, mRNA expression of Noxa and Puma was lower in the p73-knockdown cells cultured with KPT-330 compared with cells cultured with the scramble vector + KPT330 (Figure 6G).
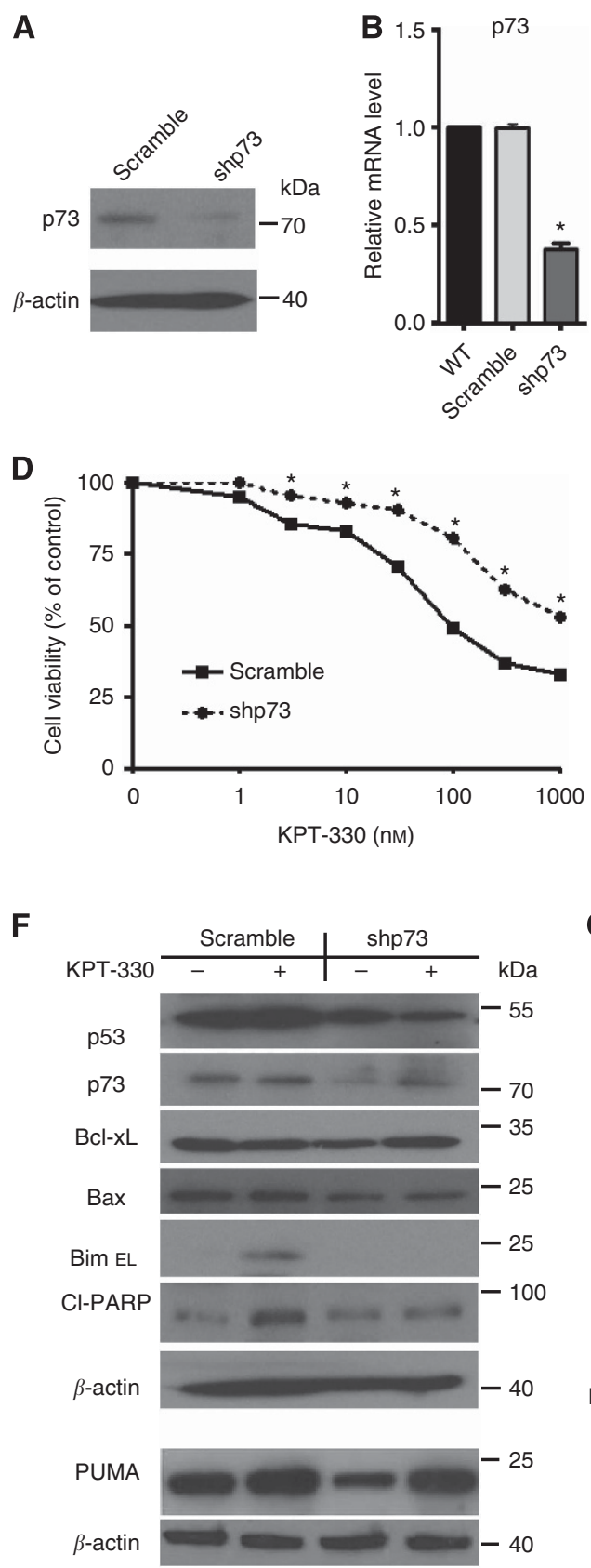
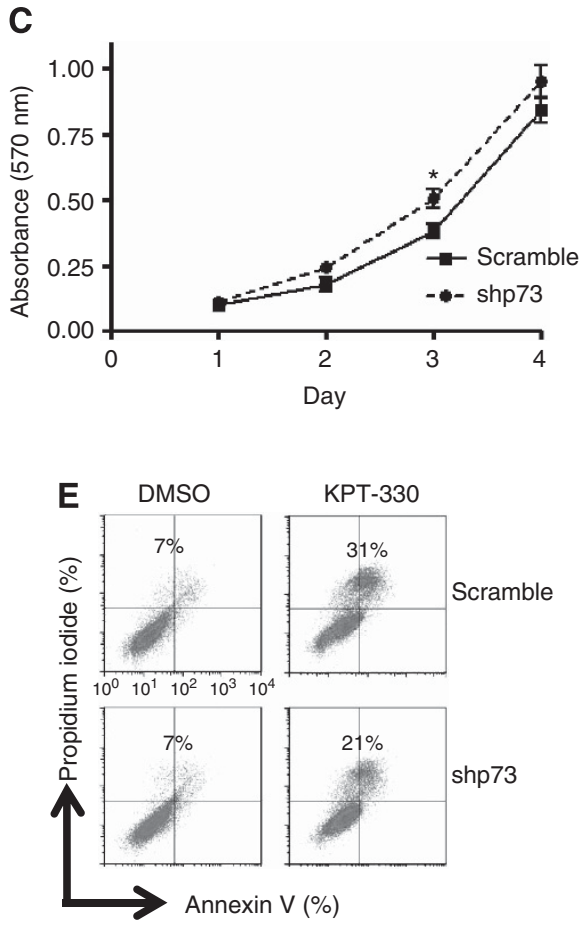

G

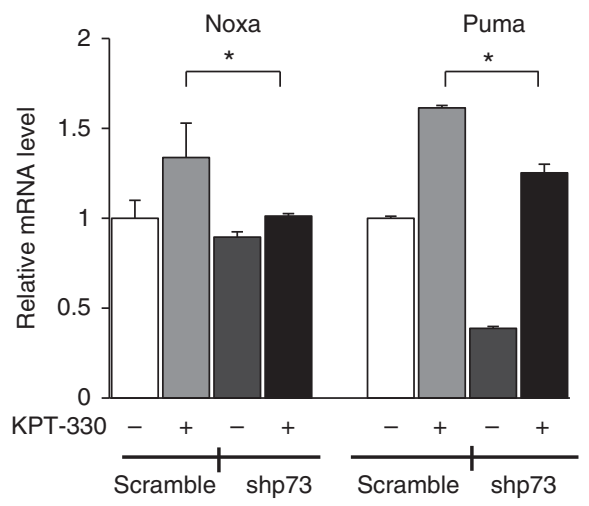

Figure 6. Stable silencing of p73 using shRNA in H1975 cells plus addition of KPT-330. H1975 cells were stably infected with either a p73-specific shRNA (shp73) or scrambled shRNA (scramble, control). p73-knockdown efficiency was evaluated by immunoblot (A) (densitometry shows $64 \%$ silencing of p73 in cells having shRNA p73) and quantitative RT-PCR (B). (C) Cell proliferation was measured by MTT assay after 1-4 days of culture. (D) Growth curves of H1975 cells stably carrying shp73 cells or scramble vector cultured with KPT-330 (0, 1, 3, 10, 30, 100, 320, and 1000 nm, 3 days). (E) H1975 cells with either stable p73 knockdown or scrambled vector were exposed to KPT-330 (50 nM, 24 h) or DMSO and analysed by flow cytometry for apoptosis (annexin V/propidium iodide positivity). Numbers in the figure represent percentage of apoptotic cells (annenxin $\mathrm{V}$ alone $+\mathrm{Pl}$ alone + double positive). (F) Immunoblots of whole-cell extracts of $\mathrm{H} 1975$ cells either with or without stably containing shp73 \pm KPT-330 (1000 nm, 24 h). (G) mRNA levels measured by quantitative RT-PCR of cells as described in panel F. Results for panels B, C, D, and $\mathbf{G}$ represent the mean \pm s.d. of three experiments done in triplicate. ${ }^{\star} P<0.05$. 

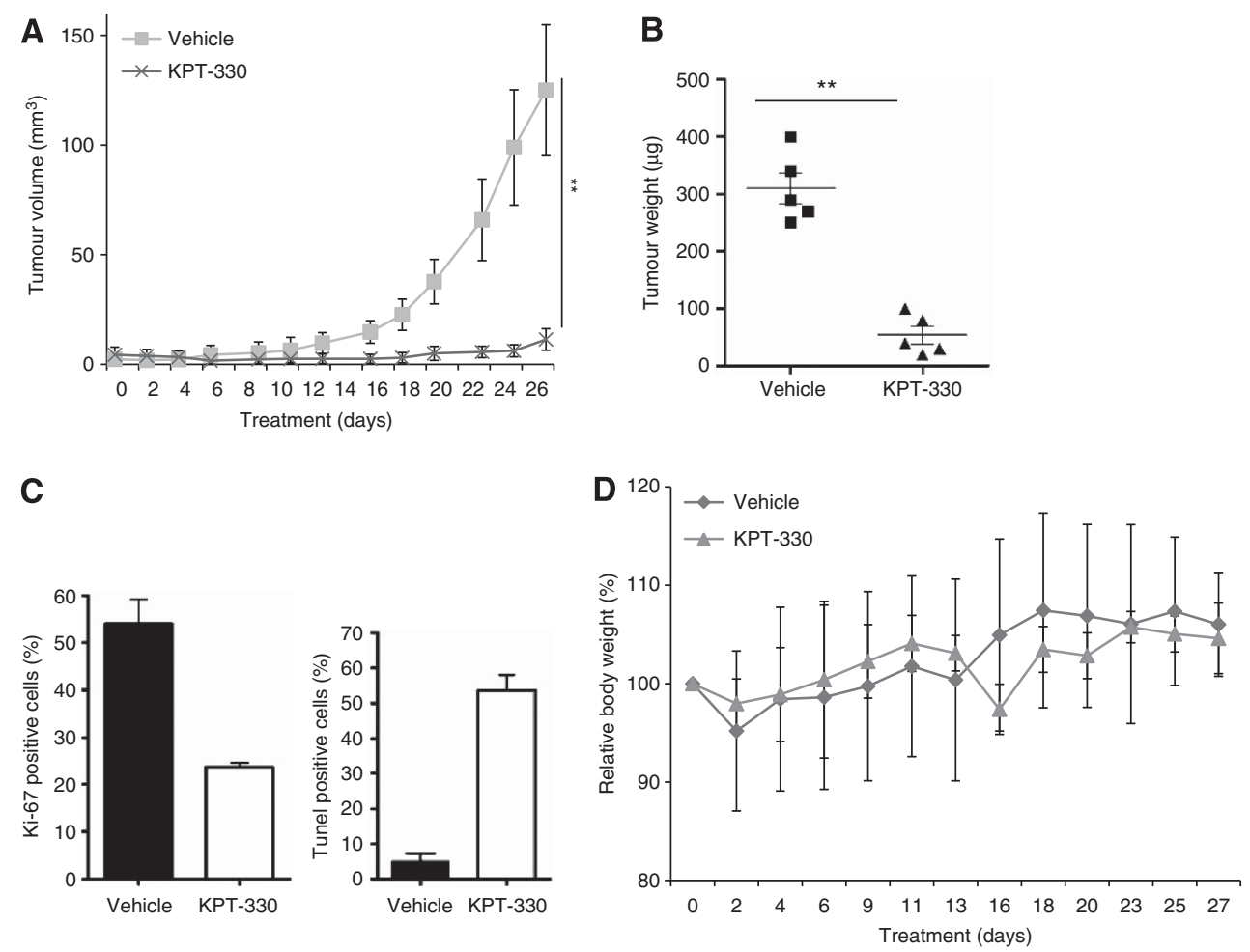

Figure 7. KPT-330 inhibits the growth of NSCLC xenografts. (A) Tumour volume of H1975 NSCLC cells engrafted in NOD/SCID mice and gauged with either vehicle or KPT-330 (10 $\mathrm{mg} \mathrm{kg}^{-1}$, thrice weekly $\times 4$ weeks); (B) weights and size of tumours after treatment of mice for 28 days as stated above. (C) Tumour tissues were collected at the end of the treatment and immunohistochemically stained for Ki-67 and TUNEL. Data are based on counting 100 cells in triplicate. Differences in each groups indicate statistical significance by one-way analysis of variance analysis $(P<0.01)$ (bottom panel). Means \pm s.d. are shown at the end of the study. (D) Body weights of mice were measured three or four times per week. ${ }^{\star \star} P<0.01$.

Table 2. Analysis of blood samples after treatment of mice in vivo

\begin{tabular}{|c|c|c|}
\hline \multirow[b]{2}{*}{ Blood values } & \multicolumn{2}{|c|}{ Treatment } \\
\hline & Vechicle & $\begin{array}{c}\text { KPT-330 } \\
\left(10 \mathrm{mg} \mathrm{kg}^{-1}\right)\end{array}$ \\
\hline WBC ( $\times 1000$ per $\mu l)($ range, 2.9-20.9) & $4.6 \pm 1.5$ & $4.0 \pm 0.3$ \\
\hline Neut $(\times 1000$ per $\mu l)($ range, $0.15-7.9)$ & $1.2 \pm 0.29$ & $1.26 \pm 0.5$ \\
\hline HCT (\%) (range, 34-53) & $34.8 \pm 4.9$ & $46.2 \pm 7.5$ \\
\hline PLT ( $\times 1000$ per $\mu$ l) (range, 685-1436) & $622 \pm 82$ & $786 \pm 180$ \\
\hline Alb $\left(\mathrm{gl}^{-1}\right)$ (range, 25-30) & $34.7 \pm 1.5$ & $36.5 \pm 0.6$ \\
\hline ALP $\left(\mathrm{UI}^{-1}\right)($ range, $35-96)$ & $82 \pm 22.8$ & $96 \pm 18$ \\
\hline $\operatorname{ALT}\left(\mathrm{UI}^{-1}\right)$ (range, $\left.17-77\right)$ & $29 \pm 5.2$ & $46.2 \pm 10.2$ \\
\hline CREAT $\left(\mathrm{mg} \mathrm{dl}^{-1}\right.$ ) (range, 0.2-0.9) & $0.12 \pm 0.01$ & $0.062 \pm 0.01$ \\
\hline \multicolumn{3}{|c|}{$\begin{array}{l}\text { Abbreviations: Alb = albumin; ALP = alkaline phosphatase; } A L T=\text { alanine aminotransferase; } \\
C R E A T=\text { creatinine; } H C T=\text { haematocrit; Neut }=\text { neutrophils; } P L T=\text { platelet; } W B C=\text { white } \\
\text { blood cell. Mice were randomly divided into two groups (five mice per group): orally treated } \\
\text { with vehicle ( } 0.6 \% \text { w } / v \text { aqueous Pluronic F- } 68) \text { or } K P T-330\left(10 \mathrm{mg} \mathrm{kg}^{-1} \text {, thrice weekly } \times 4\right. \\
\text { weekly). Mice were given Nutri-Cal (tomlyn) during therapy to allow robust nutrition. } \\
\text { Mean } \pm \text { s.d. of NOD/SCID mice. }\end{array}$} \\
\hline
\end{tabular}

Antitumour activity of KPT-330 against human NSCLC xenografts growing in vivo. H1975 NSCLC xenografts were established in NOD/SCID mice (outlined in the Materials and Methods). These cells have the T790M EGFR mutation rendering them resistant to inhibition by the TKIs gefitinib and erlotinib. Single-agent KPT-330 resulted in a mark inhibition of tumour growth when compared with vehicle-treated controls (Figure 7A and B). Immunohistochemistry analysis showed decreased Ki-67-positive cells (measure of cell growth) and an increased percent of TUNEL-positive cells (increased apoptosis) produced by KPT-330 (Figure 7C). These findings established the efficacy of KPT-330 against NSCLC cells in vivo. Importantly, this therapy did not have a significant effect on body weight compared with the vehicle group (mean relative body weight for vehicle versus KPT-330 cohorts: $106 \%$ and $105 \%$ body weight compared with their mean starting weight, respectively) (Figure 7D). In addition, we analysed peripheral blood after the 28-day treatment (Table 2). KPT-330-treated mice had no significant alterations of their total white blood cells as well as neutrophils and platelet counts, haematocrit, as well as their serum levels of albumin, alkaline phosphatase, ALT, and creatinine compared with vehicle group. These results suggest that the KPT-330 has promising therapeutic applications for the treatment of NSCLC patients associated with minimal toxicity.

\section{DISCUSSION}

Previous reports demonstrated that the natural product LMB, a CRM1 inhibitor, had anticancer activity. But because of its significant toxicity, trials with this drug were discontinued (Newlands et al, 1996). Also, significant animal toxicity was noted with LMB (Mutka et al, 2009). However, the marked gastrointestinal toxicity of $\mathrm{LMB}$ was not based on its ability to inhibit CRM1 as LMB derivatives with improved pharmacologic properties, but retaining CRM1 inhibitory capacity displayed much less toxicity (Mutka et al, 2009; Lapalombella et al, 2012). Both classes of CRM1 inhibitors (LMB and SINE compounds) bind to CYS 539 in the cargo-binding grove of SC-CRM1. However, LMB fills most of the groove, while SINE compounds occupy only around $40 \%$ of the groove. Sun et al (2013) also demonstrated that LMB, but not 
SINE, undergoes hydrolysis following the binding to CRM1, resulting in the decreased affinity of LMB to CRM1. In addition, the authors showed that LMB binding to CRM1 is not reversible even following $24 \mathrm{~h}$ of incubation, while SINE binding is reversible at $24 \mathrm{~h}$. Therefore, the improved toxicity profile of SINE compounds compared with LMB may result from their reversibility of binding to CRM1, allowing 'normal' cells to recover.

p53 is mutated in more than half of all human cancers, leading to a variety of biological effects and often associated with a poor clinical outcome (Freedman and Levine, 1998; Lecane et al, 2003; Hoshino et al, 2008). Nuclear export of this protein is mediated exclusively through CRM1 (Stommel et al, 1999). Previous studies showed that LMB induced p53 activation, suggesting this was the key to inducing growth arrest associated with apoptosis in prostate cancers (Lecane et al, 2003), neuroblastomas (Smart et al, 1999), and melanoma (Pathria et al, 2012). Recently, a study showed that p53 was a critical mediator of KPT-induced differentiation and apoptosis of acute myeloid leukaemia cells (Ranganathan et al, 2012). Interestingly, we observed that KPT-330 induced apoptosis in both p53-wt and -mut NSCLC cells. We observed that KPT-330 increased the levels of p73. As a transcription factor, p73 shares structural and functional similarities with $\mathrm{p} 53$. In cancer cells that express p53-wt, p73 cooperates with p53 to induce apoptosis; whereas in p53-mutant cancer cells, p73 has been reported to cause apoptosis via activation of p53-inducible genes (Irwin, 2004; Moll and Slade, 2004; Vayssade et al, 2005; Chung and Irwin, 2010). $\mathrm{p} 73$, similar to $\mathrm{p} 53$, is upregulated in response to a subset of DNA-damaging agents including cisplatin, inducing expression of apoptosis regulated genes including Bax, Bim, Noxa, and Puma (Moll \& Slade, 2004; Vilgelm et al, 2008; Lunghi et al, 2009; Zawacka-Pankau et al, 2010). In addition, tumours often have a p53 missense mutation at R175H, R248H, R249S, or R273H in human cancers. These $\mathrm{p} 53$-mutant proteins retain the ability to bind to $\mathrm{p} 73$ and transactivate endogenous CDKN1A, suppressing cell proliferation (Willis et al, 2003). We showed that KPT-330 induced apoptosis in $\mathrm{H} 1975$ cells (R273H, mutation of p53) associated with expression of CDKN1A. Silencing of p73 (shRNA p73) blunted the ability of KPT-330 to slow the growth of these NSCLC cells. p73 has been shown to be an important determinant of chemosensitivity in humans cancers (Irwin et al, 2003) and has an important role in cisplatin-induced apoptosis of tumours (Al-Bahlani et al, 2011). Taken together, p73 may have a significant role in the antiproliferative activity of KPT-330 wild-type and p53-mutant NSCLC cells.

In our study, two of the NSCLC cell lines have a T790M mutation in exon 20 of EGFR, making them resistant to both TKIs (gefitinib and erlotinib) (Sharma et al, 2007). But these cells were sensitive to the antiproliferative effects of KPT-330 showing that KPT-330 can inhibit growth of NSCLC cells even after their loss of responsiveness to a TKI. Furthermore, 5 of 11 of the NSCLC cell lines had either a K- or N-RAS mutation, 1 of 11 had loss of phosphatase and tensin homologue, and 2 of 11 NSCLC had PIK3CA mutations. KPT-330 had antiproliferative activity against each of these NSCLC cell lines. Thus, KPT-330 might have unique abilities to inhibit growth of tumour cells containing mutant tumour suppressor genes or activated oncogenes.

In conclusion, the present study shows for the first time that KPT-330 has prominent in vitro and in vivo antitumour activity against NSCLC cells. KPT-330 inhibited cell proliferation and induced apoptosis of NSCLC cells in vitro and in vivo. The drug was effective regardless of the mutational status of either $p 53$, EGFR, RAS, PI3K, or phosphatase and tensin homologue. The drug also reduced levels of CRM1 protein, and produced a significant nuclear accumulation of p53 and p73. Combination therapy with KPT-330 and cisplatin displayed synergistic antiproliferative activity in vitro. Treatment of mice bearing NSCLC tumours with oral KPT-330 significantly reduced the size of their tumours. These data suggest that KPT-330 either alone or in combination with platium-based regimens may be effective in the treatment of NSCLC patients despite the heterogeneity of this disease.

\section{ACKNOWLEDGEMENTS}

This research was supported by the National Research Foundation Singapore and the Singapore Ministry of Education under the Research Centres of Excellence initiative as well as the Singapore Ministry of Health's National Medical Research Council under its Singapore Translational Research (STaR) Investigator Award to H. Phillip Koeffler, the National Research Foundation Singapore and the Singapore Ministry of Education under the Research Centres of Excellence initiative as well as NIH grant R01CA026038-35. We also thank Olivia Harrison and Steven and Blanche Koegler for their support in this study.

\section{CONFLICT OF INTEREST}

MK and SS are employees of Karyopharm Therapeutics, a biopharmaceutical company that develops selective inhibitors of nuclear export-targeted therapeutics.

\section{REFERENCES}

Al-Bahlani S, Fraser M, Wong AY, Sayan BS, Bergeron R, Melino G, Tsang BK (2011) P73 regulates cisplatin-induced apoptosis in ovarian cancer cells via a calcium/calpain-dependent mechanism. Oncogene 30: 4219-4230.

Aloisi A, Di Gregorio S, Stagno F, Guglielmo P, Mannino F, Sormani MP, Bruzzi P, Gambacorti-Passerini C, Saglio G, Venuta S, Giustolisi R, Messina A, Vigneri P (2006) BCR-ABL nuclear entrapment kills human CML cells: ex vivo study on 35 patients with the combination of imatinib mesylate and leptomycin B. Blood 107: 1591-1598.

Azmi AS, Aboukameel A, Bao B, Sarkar FH, Philip PA, Kauffman M, Shacham S, Mohammad RM (2013a) Selective inhibitors of nuclear export block pancreatic cancer cell proliferation and reduce tumor growth in mice. Gastroenterology 144: 447-456.

Azmi AS, Al-Katib A, Aboukameel A, McCauley D, Kauffman M, Shacham S, Mohammad RM (2013b) Selective inhibitors of nuclear export for the treatment of non-Hodgkin's lymphomas. Haematologica 98: 1098-1106.

Chung J, Irwin MS (2010) Targeting the p53-family in cancer and chemosensitivity: triple threat. Curr Drug Targets 11: 667-681.

Etchin J, Sanda T, Mansour MR, Kentsis A, Montero J, Le BT, Christie AL, McCauley D, Rodig SJ, Kauffman M, Shacham S, Stone R, Letai A, Kung AL, Thomas Look A (2013a) KPT-330 inhibitor of CRM1 (XPO1)mediated nuclear export has selective anti-leukaemic activity in preclinical models of T-cell acute lymphoblastic leukaemia and acute myeloid leukaemia. Br J Haematol 161: 117-127.

Etchin J, Sun Q, Kentsis A, Farmer A, Zhang ZC, Sanda T, Mansour MR, Barcelo C, McCauley D, Kauffman M, Shacham S, Christie AL, Kung AL, Rodig SJ, Chook YM, Look AT (2013b) Antileukemic activity of nuclear export inhibitors that spare normal hematopoietic cells. Leukemia 27: $66-74$.

Fornerod M, Ohno M, Yoshida M, Mattaj IW (1997) CRM1 is an export receptor for leucine-rich nuclear export signals. Cell 90: 1051-1060.

Freedman DA, Levine AJ (1998) Nuclear export is required for degradation of endogenous p53 by MDM2 and human papillomavirus E6. Mol Cell Biol 18: 7288-7293.

Fukuda M, Asano S, Nakamura T, Adachi M, Yoshida M, Yanagida M, Nishida E (1997) CRM1 is responsible for intracellular transport mediated by the nuclear export signal. Nature 390: 308-311.

Hoshino I, Matsubara H, Komatsu A, Akutsu Y, Nishimori T, Yoneyama Y, Murakami K, Sakata H, Matsushita K, Miyazawa Y, Brooks R, Yoshida M, Ochiai T (2008) Combined effects of p53 gene therapy and leptomycin B in human esophageal squamous cell carcinoma. Oncology 75: 113-119. 
Huang TT, Kudo N, Yoshida M, Miyamoto S (2000) A nuclear export signal in the N-terminal regulatory domain of IkappaBalpha controls cytoplasmic localization of inactive NF-kappaB/IkappaBalpha complexes. Proc Natl Acad Sci USA 97: 1014-1019.

Irwin MS (2004) Family feud in chemosensitvity: p73 and mutant p53. Cell Cycle 3: 319-323.

Irwin MS, Kondo K, Marin MC, Cheng LS, Hahn WC, Kaelin Jr. WG (2003) Chemosensitivity linked to p73 function. Cancer Cell 3: 403-410.

Johnson JL, Pillai S, Chellappan SP (2012) Genetic and biochemical alterations in non-small cell lung cancer. Biochem Res Int 2012: 940405.

Kau TR, Silver PA (2003) Nuclear transport as a target for cell growth. Drug Discov Today 8: 78-85.

Kojima K, Kornblau SM, Ruvolo V, Dilip A, Duvvuri S, Davis RE, Zhang M, Wang Z, Coombes KR, Zhang N, Qiu YH, Burks JK, Kantarjian H, Shacham S, Kauffman M, Andreeff M (2013) Prognostic impact and targeting of CRM1 in acute myeloid leukemia. Blood 121: 4166-4174.

Komarov PG, Komarova EA, Kondratov RV, Christov-Tselkov K, Coon JS, Chernov MV, Gudkov AV (1999) A chemical inhibitor of p53 that protects mice from the side effects of cancer therapy. Science 285: 1733-1737.

Lapalombella R, Sun Q, Williams K, Tangeman L, Jha S, Zhong Y, Goettl V, Mahoney E, Berglund C, Gupta S, Farmer A, Mani R, Johnson AJ, Lucas D, Mo X, Daelemans D, Sandanayaka V, Shechter S, McCauley D, Shacham S, Kauffman M, Chook YM, Byrd JC (2012) Selective inhibitors of nuclear export show that CRM1/XPO1 is a target in chronic lymphocytic leukemia. Blood 120: 4621-4634.

Lecane PS, Kiviharju TM, Sellers RG, Peehl DM (2003) Leptomycin B stabilizes and activates p53 in primary prostatic epithelial cells and induces apoptosis in the LNCaP cell line. Prostate 54: 258-267.

Leong CO, Vidnovic N, DeYoung MP, Sgroi D, Ellisen LW (2007) The p63/p73 network mediates chemosensitivity to cisplatin in a biologically defined subset of primary breast cancers. J Clin Invest 117: 1370-1380.

Lu C, Shao C, Cobos E, Singh KP, Gao W (2012) Chemotherapeutic sensitization of leptomycin B resistant lung cancer cells by pretreatment with doxorubicin. PLoS One 7: e32895.

Lunghi P, Costanzo A, Mazzera L, Rizzoli V, Levrero M, Bonati A (2009) The p53 family protein p73 provides new insights into cancer chemosensitivity and targeting. Clin Cancer Res 15: 6495-6502.

Moll UM, Slade N (2004) p63 and p73: roles in development and tumor formation. Mol Cancer Res 2: 371-386.

Murphy PJ, Galigniana MD, Morishima Y, Harrell JM, Kwok RP, Ljungman M, Pratt WB (2004) Pifithrin-alpha inhibits p53 signaling after interaction of the tumor suppressor protein with hsp90 and its nuclear translocation. J Biol Chem 279: 30195-30201.

Mutka SC, Yang WQ, Dong SD, Ward SL, Craig DA, Timmermans PB, Murli S (2009) Identification of nuclear export inhibitors with potent anticancer activity in vivo. Cancer Res 69: 510-517.

Newlands ES, Rustin GJ, Brampton MH (1996) Phase I trial of elactocin. Br J Cancer 74: 648-649.

Noske A, Weichert W, Niesporek S, Roske A, Buckendahl AC, Koch I, Sehouli J, Dietel M, Denkert C (2008) Expression of the nuclear export protein chromosomal region maintenance/exportin 1/Xpo1 is a prognostic factor in human ovarian cancer. Cancer 112: 1733-1743.

Ohashi K, Maruvka YE, Michor F, Pao W (2013) Epidermal growth factor receptor tyrosine kinase inhibitor-resistant disease. J Clin Oncol 31 1070-1080.

Ossareh-Nazari B, Bachelerie F, Dargemont C (1997) Evidence for a role of CRM1 in signal-mediated nuclear protein export. Science 278: 141-144.

Pathria G, Wagner C, Wagner SN (2012) Inhibition of CRM1-mediated nucleocytoplasmic transport: triggering human melanoma cell apoptosis by perturbing multiple cellular pathways. J Invest Dermatol 132 2780-2790.

Ranganathan P, Yu X, Na C, Santhanam R, Shacham S, Kauffman M, Walker A, Klisovic R, Blum W, Caligiuri M, Croce CM, Marcucci G, Garzon R (2012) Preclinical activity of a novel CRM1 inhibitor in acute myeloid leukemia. Blood 120: 1765-1773.

Rodriguez MS, Thompson J, Hay RT, Dargemont C (1999) Nuclear retention of IkappaBalpha protects it from signal-induced degradation and inhibits nuclear factor kappaB transcriptional activation. J Biol Chem 274: 9108-9115.
Salas Fragomeni RA, Chung HW, Landesman Y, Senapedis W, Saint-Martin JR, Tsao H, Flaherty KT, Shacham S, Kauffman M, Cusack JC (2013) CRM1 and BRAF inhibition synergize and induce tumor regression in BRAF-Mutant Melanoma. Mol Cancer Ther 12: 1171-1179.

Sharma SV, Bell DW, Settleman J, Haber DA (2007) Epidermal growth factor receptor mutations in lung cancer. Nat Rev Cancer 7: 169-181.

Shen A, Wang Y, Zhao Y, Zou L, Sun L, Cheng C (2009) Expression of CRM1 in human gliomas and its significance in p27 expression and clinical prognosis. Neurosurgery 65: 153-159.

Smart P, Lane EB, Lane DP, Midgley C, Vojtesek B, Lain S (1999) Effects on normal fibroblasts and neuroblastoma cells of the activation of the p53 response by the nuclear export inhibitor leptomycin B. Oncogene 18: 7378-7386.

Sohn D, Graupner V, Neise D, Essmann F, Schulze-Osthoff K, Janicke RU (2009) Pifithrin-alpha protects against DNA damage-induced apoptosis downstream of mitochondria independent of p53. Cell Death Differ 16: 869-878.

Stewart DJ (2010) Tumor and host factors that may limit efficacy of chemotherapy in non-small cell and small cell lung cancer. Crit Rev Oncol Hematol 75: 173-234.

Stommel JM, Marchenko ND, Jimenez GS, Moll UM, Hope TJ, Wahl GM (1999) A leucine-rich nuclear export signal in the p53 tetramerization domain: regulation of subcellular localization and p53 activity by NES masking. EMBO J 18: 1660-1672.

Sun Q, Carrasco YP, Hu Y, Guo X, Mirzaei H, Macmillan J, Chook YM (2013) Nuclear export inhibition through covalent conjugation and hydrolysis of Leptomycin B by CRM1. Proc Natl Acad Sci USA 110: 1303-1308.

Tai YT, Landesman Y, Acharya C, Calle Y, Zhong MY, Cea M, Tannenbaum D, Cagnetta A, Reagan M, Munshi AA, Senapedis W, Saint-Martin JR, Kashyap T, Shacham S, Kauffman M, Gu Y, Wu L, Ghobrial I, Zhan F, Kung AL, Schey SA, Richardson P, Munshi NC, Anderson KC (2013) CRM1 inhibition induces tumor cell cytotoxicity and impairs osteoclastogenesis in multiple myeloma: molecular mechanisms and therapeutic implications. Leukemia 28: 155-165.

Takenaka Y, Fukumori T, Yoshii T, Oka N, Inohara H, Kim HR, Bresalier RS, Raz A (2004) Nuclear export of phosphorylated galectin-3 regulates its antiapoptotic activity in response to chemotherapeutic drugs. Mol Cell Biol 24: 4395-4406.

Turner JG, Dawson J, Sullivan DM (2012) Nuclear export of proteins and drug resistance in cancer. Biochem Pharmacol 83: 1021-1032.

Turner JG, Marchion DC, Dawson JL, Emmons MF, Hazlehurst LA, Washausen P, Sullivan DM (2009) Human multiple myeloma cells are sensitized to topoisomerase II inhibitors by CRM1 inhibition. Cancer Res 69: 6899-6905.

van der Watt PJ, Maske CP, Hendricks DT, Parker MI, Denny L, Govender D, Birrer MJ, Leaner VD (2009) The Karyopherin proteins, Crm1 and Karyopherin beta1, are overexpressed in cervical cancer and are critical for cancer cell survival and proliferation. Int J Cancer 124: 1829-1840.

Vayssade M, Haddada H, Faridoni-Laurens L, Tourpin S, Valent A, Benard J, Ahomadegbe JC (2005) P73 functionally replaces p53 in Adriamycintreated, p53-deficient breast cancer cells. Int J Cancer 116: 860-869.

Vilgelm A, El-Rifai W, Zaika A (2008) Therapeutic prospects for p73 and p63: rising from the shadow of p53. Drug Resist Updat 11: 152-163.

Willis AC, Pipes T, Zhu J, Chen X (2003) p73 can suppress the proliferation of cells that express mutant p53. Oncogene 22: 5481-5495.

Zawacka-Pankau J, Kostecka A, Sznarkowska A, Hedstrom E, Kawiak A (2010) p73 tumor suppressor protein: a close relative of p53 not only in structure but also in anti-cancer approach? Cell Cycle 9: 720-728.

Zhang K, Wang M, Tamayo AT, Shacham S, Kauffman M, Lee J, Zhang L, Ou Z, Li C, Sun L, Ford RJ, Pham LV (2013) Novel selective inhibitors of nuclear export CRM1 antagonists for therapy in mantle cell lymphoma. Exp Hematol 41(67-78): e4.

Zhang KJ, Wang M (2012) Potential effects of CRM1 inhibition in mantle cell lymphoma. Chin J Cancer Res 24: 374-387.

This work is published under the standard license to publish agreement. After 12 months the work will become freely available and the license terms will switch to a Creative Commons AttributionNonCommercial-Share Alike 3.0 Unported License.

Supplementary Information accompanies this paper on British Journal of Cancer website (http://www.nature.com/bjc) 